\title{
Analysis of Poly(Lactic-co-Glycolic Acid)/Poly(Isoprene) Polymeric Blend for Application as Biomaterial
}

\author{
Douglas Ramos Marques, Luis Alberto dos Santos \\ Universidade Federal do Rio Grande do SuI - UFRGS \\ Luciano Ferraz Schopf, José Carlos Soares de Fraga \\ Hospital de Clínicas de Porto Alegre - UFRGS
}

\begin{abstract}
The application of renewable raw materials encourages research in the biopolymers area. The Poly(Lacticco-Glycolic Acid)/Poly(Isoprene) (PLGA/IR) blend combines biocompatibility for application in the health field with excellent mechanical properties. The blend was obtained by solubilization of polymers in organic solvents. To investigate the polymer thermochemical properties, FTIR and DSC were applied. To investigate the composition's influence over polymer mechanical properties, tensile and hardness test were applied. To analyze the blends response in the cell environment, a stent was produced by injection molding process, and Cell Viability Test and Previous Implantability were used. The Infrared spectra show that chemical composition is related only with polymers proportion in the blend. The calorimetry shows a partial miscibility in the blend. The tensile test shows that adding Poly(Isoprene) to Poly(Lactic-co-Glycolic Acid) induced a relevant reduction in the Young modulus, tensile stress and tenacity of the material, which was altered from the fragile raw PLGA to a ductile material. The composition did not affect the blend hardness. The cell viability test shows that the blend has potential application as biomaterial, while the first results of implantability indicate that the polymeric stent kept its original position and caused low fibrosis.
\end{abstract}

Keywords: PLGA, latex, FTIR, DSC, tensile, hardness, implantability, cell viability.

\section{Introduction}

The use of biologically derived polymers (biomacromolecules) is an important component for economic development. A new class of renewable, biodegradable, and biocompatible materials occurs through the transformation of forest and raw agricultural materials ${ }^{[1]}$. Poly (lactic-co-glycolic acid) (PLGA) is one of the most common biodegradable polymers. It is a copolymer of aliphatic esters, which has been used largely as an implant that dissolves and is absorbed by the body ${ }^{[2,3]}$. However, the application of PLGA derived orthosis/prosthesis next to soft tissues may cause injuries to the patient during the treatment, especially because of any eventual device collapse due to bioresorption ${ }^{[4]}$ In order to settle the PLGA mechanical properties, a blending procedure may be adequate.

Recent research describes promising results obtained by a polymer extracted from the tree Hevea brasiliensis ${ }^{[5]}$. Cis-1, 4-Poly(Isoprene), also known as isoprene rubber (IR) or latex, is found in the rubber of the seringueira rubber tree and obtained by the coagulation of natural latex ${ }^{[6]}$. It is shown to be highly biocompatible when applied as biomaterial ${ }^{[5]}$.

Polymeric blends are physical mixtures of two or more polymers or copolymers ${ }^{[7]}$. This is an extremely promising approach that represents one of the most quickly growing areas in polymer science ${ }^{[8,9]}$. These materials intend to obtain new characteristics through the combination of properties of different polymers ${ }^{[1,6]}$. The polymer properties can be altered through chemical modification of the polymeric chain or through a mixture of other polymers into the material ${ }^{[1]}$. A brief study about the compatibility between PLLA and IR has already been developed in the early 2000 's, but preliminary results indicating a total immiscibility of both polymers in a blend lead the project to its discontinuity ${ }^{[10]}$. However, the main idea of blending in order to reduce PLGA brittleness seems very attractive, especially achieving this property with the help of a polymer already applied on biomaterials research field.

The application of a polymeric stent as a tissue support has the main goal of avoiding a tubular structure stenosis, keeping its lumen opened. These devices are largely applied in blood vases, urethra, trachea, bronchi, besides other systems ${ }^{[4,11-13]}$. For application in respiratory system, the stent is considered a convenient treatment for patients with benign stenosis, chronicle obstructive pulmonary disease, heart diseases, diabetes, and other systemic disorders, offering immediate respiratory symptoms relief, with an improve in forced expiratory volume and, consequently, improving patient quality of life ${ }^{[13-16]}$.

The PLGA/IR blend can be classified as a solution blend, since the polymers are dissolved in a common solvent and the solvent is removed ${ }^{[7]}$. Due to the miscibility of organic polymers and solvents, it is more convenient to use such solvents as a means of blend dissolution ${ }^{[17]}$. The solubility in aliphatic esters and the applicability to cis-Poly(Isoprene) creates a suitable solvent from chloroform $\left(\mathrm{CHCl}_{3}\right)$ to obtain the blend through a solution ${ }^{[18]}$.

Corresponding author: Douglas Ramos Marques, Universidade Federal do Rio Grande do Sul - UFRGS, Av Bento Gonçalves, 9500, Setor IV, Prédio 74, Sala 125, CEP 91501-970, Porto Alegre, RS, Brasil, e-mail: douglas.marques@ufrgs.br 
Unfortunately, volatile organic solvents such as chloroform may cause health problems for people exposed to $\mathrm{it}^{[17]}$. The solvents can also have a great impact upon the structure of polymers, since, depending upon the interaction between the polymers and the solvent, the polymer may dissolve completely, either in separate phases, or present an alteration in its molecular structure $^{[19]}$.

To evaluate the blend's mechanical properties, one of the most common stress-strain test performed is tensile test. Towards it can be analyzed plastic and elastic deformation, the energy expend in each of these, besides ductility, resilience and Young's modulus. The hardness is another mechanical measurement. It indicates the material's resistance to localized plastic deformation ${ }^{[7,20]}$.

To use the solution blend as biomaterial, viability cell tests are applied to detect the occurrence of toxic effects and the biological behavior of the material on the cellular level ${ }^{[21,22]}$. Human Hepatoma (HepG2 and its derivatives) cells are successfully introduced in humans in order to study cellular metabolism and its cytotoxic and genotoxic responses to contact with determined materials ${ }^{[23,24]}$. The implantability test defines the material's behavior in vivo, the tissue response and the device performance.

The goal of this study was to investigate the occurrence of reactions and modifications among PGLA/ IR polymer blends and possible interactions caused by the use of organic solvent using Fourier Transformed Infrared spectroscopy (FTIR), as well as investigate about the influence of IR proportion over mechanical properties and find a correlation between PLGA and IR amounts, achieving a blend with, at least, partial miscibility. The study also aims at investigating the cell viability of the PLGA/IR polymer blend obtained by solubilization in chloroform, testing its potential use as biomaterial. Preliminary results of implantability tests are also reported.

\section{Experimental}

\section{Blend}

The PLGA (Purac Biomaterials - Holland) is a copolymer with proportions of $84 \mathrm{~mol} \%$ monomer L-lactate and $16 \mathrm{~mol} \%$ glycolide. The number-average molecular weight $(M n)$ was 250,000 , and presented $\mathrm{pH}$ of 7.2, was used as obtained, without previous purifications or processing. The IR (Mafer - Brazil) in the natural latex structure centrifuged at $60 \%$, presented $M n=295,000$, and was neutralized with $\mathrm{HCl} 2 \mathrm{M}$ solution at an interval of $\mathrm{pH}$ 7.2-7.8 and submitted to a drying process. The polymer was purified by a re-precipitation method, using chloroform $\left(\mathrm{CHCl}_{3}\right)$ as a solvent, and re-precipitated in methyl alcohol $\left(\mathrm{CH}_{3} \mathrm{OH}\right)^{[25]}$. Chloroform (99.8\%) (Synth - Brazil) and methyl alcohol (99.8\%) (Synth - Brazil) were used as obtained, without previous purifications or processing. The materials were dissolved in chloroform in the proper desired proportions. Once homogenized, this mixture was dried in a stove for 24 hours at $40^{\circ} \mathrm{C}$ to volatize the solvent. The blends were prepared in the following mass proportions: 100\%PLGA
(PLGA); 75\%PLGA/25\%IR (75/25); 60\%PLGA/40\%IR (60/40); 50\%PLGA/50\%IR (50/50); 100\%IR (IR).

\section{Thermochemical properties}

During the volatilization, the material was conformed in thin film format for application in FTIR tests, with the caution of getting films with the same thickness, in order to compare quantitatively the bands, connecting the band intensity with the polymers proportion in the blends. For characterization by FTIR, the spectrum of the polymeric blend in the $4000-400 \mathrm{~cm}^{-1}$ region was obtained using the Perkin Elmer model Spectrum 1000 FTIR at room temperature $\left(25^{\circ} \mathrm{C}\right)$. In order to investigate the polymers miscibility, differential scanning calorimetry (DSC) was carried on TA Instruments QS, between $-80{ }^{\circ} \mathrm{C}$ and $150{ }^{\circ} \mathrm{C}$.

\section{Mechanical properties}

For tensile and hardness tests, the samples were prepared by injection molding using a Haake Mininjet II from Thermo Scientific, with process temperature around $165^{\circ} \mathrm{C}$. The tensile test was performed using a equipment Shimadzu model Autograph AG-X, with a 50KN load cell, using a elongation rate of $2 \mathrm{~mm} / \mathrm{min}$. The hardness was carried using an indenter Mainared model G112605, Shore A scale. The samples follow the recommendations of ISO 527-1 to tensile test, and ASTM D-2240 to hardness measure.

\section{Cell viability test}

During the volatilization, the material was conformed in wire format, with approximately $\varnothing 2 \mathrm{~mm}$, by a deep coating process for the cell viability test. The HepG2 cells (ATCC HB-8605) were used in the cell viability test. $5 \times 10^{4}\left(2.63\right.$ cells $\left./ \mathrm{cm}^{2}\right)$ were sown in each well, in a 24 well-plate format. The treatment group was constituted of 10 wells with a polymeric blend $60 / 40$, while the control group was constituted of 10 wells in absence of any substances. The cells were kept in a culture with half DMEM-LG (Dubelco's Modified Eagle Medium-Low Glucose, LGC) supplemented with $10 \%$ Fetal Bovine Serum (Gibco) for 24 hours in a humid incubator at $37{ }^{\circ} \mathrm{C}$ and an atmosphere of $5 \% \mathrm{CO}_{2}$. After the treatment, the cells were detached using a solution of Tripsina-EDTA $0.25 \%$ (Gibco). The viability was evaluated by a live cell count using a Neubauer chamber with Trypan blue.

\section{Preliminary implantability test}

A spiral stent were prepared with the $60 / 40$ blend composition, by injection molding using a Haake Mininjet II from Thermo Scientific, with process temperature around $165^{\circ} \mathrm{C}$. After sterilization by ethylene oxide (EtO), the stent was implanted in a New Zeland rabbit's trachea, $5,6 \mathrm{~kg}$ weight, fallowing the main procedures commonly used in Animal Experimentation Unit of Clinics Hospital of Porto Alegre. The animal was submitted to general anesthesia and tracheal intubation by the use of intravenous isoflurane, ketamine and Midazolam. The stent was implanted towards median cervical incision. 
The stent was observed by bronchoscopy using a flexible bronchoscope for 21 days after proceeding.

\section{Results and Discussion}

\section{Thermochemical properties}

From the analysis of previously known molecular structure, we expected to find on the infrared spectrum, bands relative to PLGA in the $\mathrm{C}=\mathrm{O}$ and $\mathrm{C}-\mathrm{O}$ bonds typical of esters. It is itself, due to the structure of the IR, the variation of intensity of the bands relative to the vibrations $\mathrm{C}=\mathrm{C}$ and $=\mathrm{CH}^{[2]}$. The FTIR spectra generated by the blends are represented in Figure 1. Characteristic bands of symmetrical and asymmetrical stretchings of $\mathrm{CH}_{2}$ and $\mathrm{CH}_{3}$ groups ${ }^{[26]}$ are presented between 2980 and $2850 \mathrm{~cm}^{-1}$. Notice that the intensity of these signals is relevant for compounds with large quantities of IR. The signal decreases with the mass drop in quantity of IR in the blend. The spectrum reports an intensity of stretchings, as the major component in the blend demonstrates. Following the same behavior, bands of asymmetrical deformation of $\mathrm{CH}_{3}$ are presented in $1375 \mathrm{~cm}^{-1}$ and $\mathrm{CH}_{2}$ in $1450 \mathrm{~cm}^{-1}$, with little decrease in intensity per decrease in mass quantity of $\operatorname{IR}^{[26-28]}$.

The $1760 \mathrm{~cm}^{-1}$, in compounds with PLGA present, is seen in an acute and intense band, caused by the $\mathrm{C}=\mathrm{O}$ bond stretching of the esters ${ }^{[2,8,26,28]}$. The intensity is maintained in any composition and, as expected, is not visible in $100 \%$ IR. The $1185 \mathrm{~cm}^{-1}$ and the $1090 \mathrm{~cm}^{-1}$ are found to be bands relative to the $\mathrm{C}-\mathrm{O}$ stretchings of aliphatic polyesters ${ }^{[2,8,26,28]}$. The vibration of the IR $\mathrm{C}=\mathrm{C}$ bond appears discrete at $1663 \mathrm{~cm}^{-1}$. According to Klöpffer, $\mathrm{C}=\mathrm{C}$ stretching in IR generates low intensity bands ${ }^{[29]}$. It can also be noted in a small band that, with the decrease in mass proportion of IR in the blend, a decrease in band intensity occurs. This response from the material is plausible, given that the PLGA copolymer

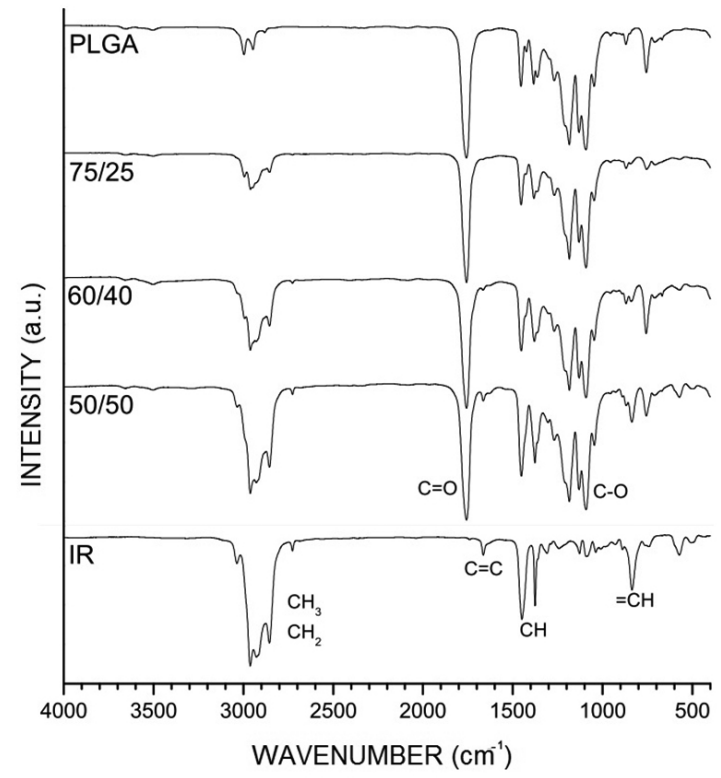

Figure 1. FTIR spectra. does not present double bonds between carbons. The $=\mathrm{C}-\mathrm{H}$ stretching is also reported with the same behavior of variation in the band found at $836 \mathrm{~cm}^{-1[28,30]}$. This band corresponds with the bending outside of the $\mathrm{C}-\mathrm{H}$ bond plan $^{[29]}$. Pandey et al. reported that the use of chloroform in PLLA (Polylactic acid) blends and PGA (Polyglycolic acid) showed significant variation in polymer structure, in relation to materials used. This variation also indicated the formation of mixtures in the molecules, turning the material similar to a copolymer and no longer a blend ${ }^{[2]}$. The absorption of aliphatic $\mathrm{C}-\mathrm{Cl}$ in chloroform is observed between $850-550 \mathrm{~cm}^{-1}$, however, when several chlorine atoms are bonded to the same carbon atom, as is the case with chloroform (trichloromethane), the bands are more intense and located at the extreme limit of the highest frequency of this range ${ }^{[31]}$. For the blends, bands were observed at $756 \mathrm{~cm}^{-1}$, mainly in the 50/50,60/40 and $100 \%$ PLGA compositions. As there is no constant behavior, it can be deduced that the signals with low intensity are relative to the $-\mathrm{C}-\mathrm{H}$ vibrations, given that this grouping is found in both polymer chains ${ }^{[32]}$.

Through DSC analysis we were able to evaluate the main polymers transition temperatures, as shown in Figure 2. The glass transition temperatures $(\mathrm{Tg})$ relative to raw PLGA and IR are $58,88{ }^{\circ} \mathrm{C}$ and $-65,74{ }^{\circ} \mathrm{C}$, respectively. In the blend 50/50, we are still able to see both Tg's holding the same position as presented for raw materials. However, for the compositions $60 / 40$ and 75/25, the $\mathrm{Tg}$ related with IR shows an expressive deviation, from approximately $-66{ }^{\circ} \mathrm{C}$ to around $25{ }^{\circ} \mathrm{C}$. In specific to the $60 / 40$ blend, the PLGA Tg also show a deviation, from $58,88^{\circ} \mathrm{C}$ to $48,95{ }^{\circ} \mathrm{C}$. This approximation of glass transition temperatures indicates a partial miscibility between the polymers at this blends proportion ${ }^{[8,10]}$.

\section{Mechanical properties}

The tensile test recorded the load and elongation data and, consequently, the relation between material's stress $(\sigma)$ and strain $(\varepsilon)$, which is represented in Figure 3 for raw PLGA and different blend's compositions.

Analyzing the diagram, it is notable that the raw PLGA presents tension stress values considerably higher than the presented by any blend's composition. This mechanical answer may be related the raw PLGA's higher crystallinity, as well as the presence of an amorphous (IR)

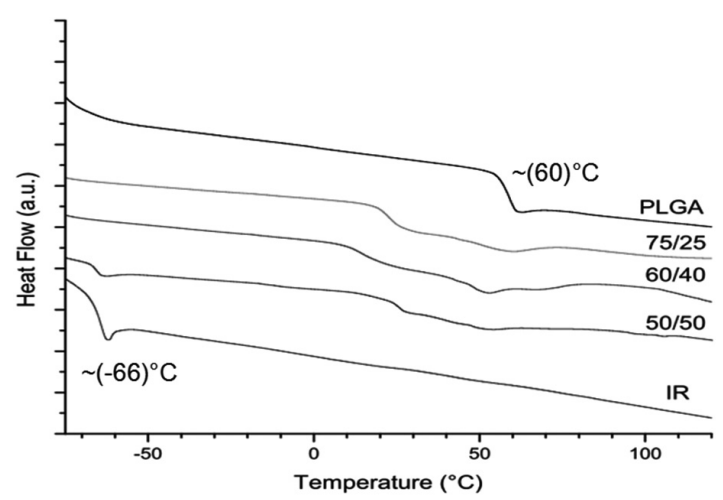

Figure 2. DSC curves. 
phase in the blends ${ }^{[20,33]}$. Values for general properties were calculate based on the curves, and are presented in Table 1.

For each curve, at the yielding point, was calculated the Young's modulus. The presence of IR in the material reduced considerably the modulus value. The high modulus presented by PLGA represents the material's capacity to tolerate tensile stress. Upadhyay et al. reported that the addition of semicrystalline materials increases the blends crystallinity, contributing to Young's modulus increase ${ }^{[34]}$. Therefore, the inverse behavior, with addition of amorphous materials, may have an influence on modulus reduction. In polymers, beyond yielding point, tension applied can be responsible by the fluency of polymeric chains one over another, resulting in irreversible deformation ${ }^{[7]}$. The blend's tensile stress was considerably reduced by the addition of IR to the PLGA. It can be noticed in both, maximum point and break point. However, the tensile strain didn't show a significant difference, despite the slight reduction, between blends and PLGA.

Calculating the area under the curves in Figure 3, we can analyze the tenacity (area under the curve up to the break) and the resilience (area under the curve up to the yielding point). Once the resilience is the energy expended in elastic deformation and the tenacity is the energy expended in the deformation to the rupture, it's normal the first value to be lower than the second. The addition of IR to the PLGA reduce significantly both properties in the material. However, relating tenacity

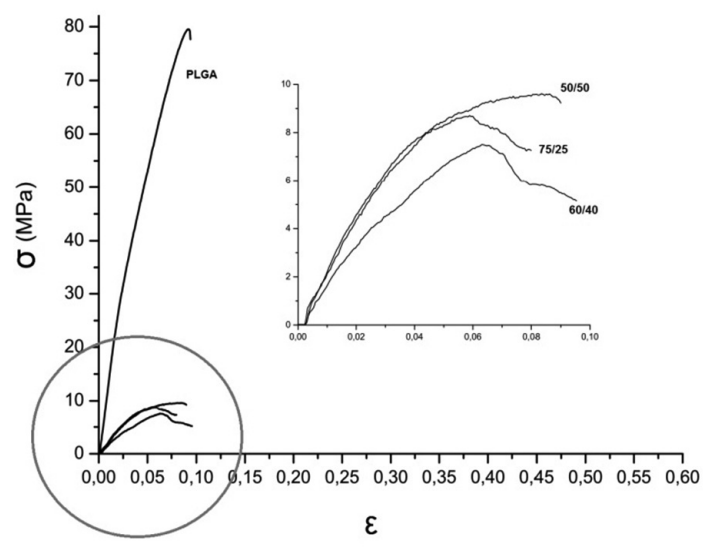

Figure 3. tensile stress-strain diagram.

Table 1. Analysis of mechanical properties.

\begin{tabular}{lcccc}
\hline \multicolumn{1}{c}{ Property } & PLGA & $\mathbf{7 5 / 2 5}$ & $\mathbf{6 0 / 4 0}$ & $\mathbf{5 0 / 5 0}$ \\
\hline Young's modulus (MPa) & 891.2 & 182.05 & 137.79 & 171.07 \\
$\begin{array}{l}\text { Tensile Stress at maximum } \\
\text { (Mpa) }\end{array}$ & 79.98 & 9.09 & 7.64 & 9.78 \\
$\begin{array}{l}\text { Tensile Stress at break (MPa) } \\
\text { Tensile Strain at maximum }\end{array}$ & 74.66 & 7.70 & 5.87 & 8.81 \\
$\begin{array}{l}\text { stress (mm/mm) } \\
\text { Tensile Strain at break }\end{array}$ & 0.094 & 0.067 & 0.072 & 0.089 \\
$\begin{array}{l}\mathrm{mm} / \mathrm{mm}) \\
\text { Tenacity }\left(\mathrm{J} / \mathrm{cm}^{3}\right)\end{array}$ & 0.080 & 0.097 & 0.097 \\
Resilience $\left(\mathrm{J} / \mathrm{cm}^{3}\right)$ & 4.45 & 0.49 & 0.47 & 0.61 \\
\hline
\end{tabular}

and resilience of each composition, it's possible see that blends expend more energy in plastic deformation than raw PLGA. While the blends use around $60 \%$ of its energy in permanent deformation, to PLGA this rate decrease to $10 \%$, what means that the raw polymer has a brittle behavior compared to the ductile behavior seen in the blends.

Despite the incontestable fall in the maximum stress rates, adding polyisoprene to the blend, it was possible to see a change of mechanical behavior, from a fragile behavior to a extremily ductile behavior. This fact leads the blend to be a material that may be molded right before the surgery procedure, as well as suffer mechanical charges during its application, without compromise its integrity and the development of its functions in vivo.

For the hardness test, were found values around 40SHa to all the blend's compositions. The result is reasonable, since the PLGA presented hardness $81 \mathrm{SHa}$ and IR has hardness $29 \mathrm{SHa}^{[35]}$. Despite the fact that the composition doesn't have a direct relation with the hardness results, the hardness is an empiric measure, applied with controlling aims, and that doesn't relates to any other materials mechanical properties ${ }^{[36]}$.

\section{Cell viability test}

The use of the cell culture technique, in this case, was intended to determine the Cell Lysis caused by health products, materials and/or their extracts ${ }^{[37]}$. The cell count performed generated the graph of average cell survival and standard deviation, shown in Figure 4.

The effect of the incubation of the material upon the number of cells was evaluated by an analysis of variance (ANOVA), with a degree of statistical reliability of $95 \%$ $(\alpha=0.05)$, as shown in Table $2^{[38,39]}$. Given that the value of $F$ is less than the value of Critical $F$, no significant difference was found between the Treatment Group and the Control Group.

\section{Preliminary implantability test}

The tracheotomy was used to implant the polymeric stent into rabbit's trachea. The procedure counted with a transversal incision with the animal in dorsal decubitus position, stent positioning through aperture, and later sewing with a resorbable polymeric thread. The procedure is showed in Figure 5.

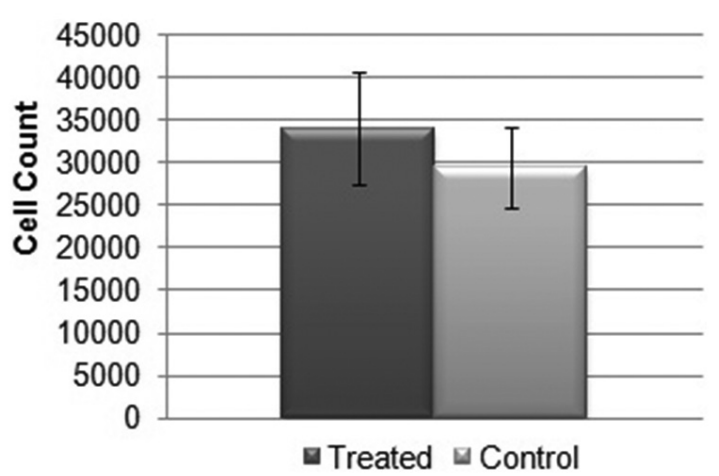

Figure 4. Cell survival average. 
Table 2. Analysis of variance.

\begin{tabular}{lcccccc}
\hline Source of variation & SQ & Gl & MQ & F & P & Critical F \\
\hline Between groups & 101250000 & 1 & 101250000 & 2,97551 & 0,10166 & 4,413873 \\
Within each group & 612500000 & 18 & 34027777,8 & & & \\
Total & 713750000 & 19 & & & & \\
\hline
\end{tabular}

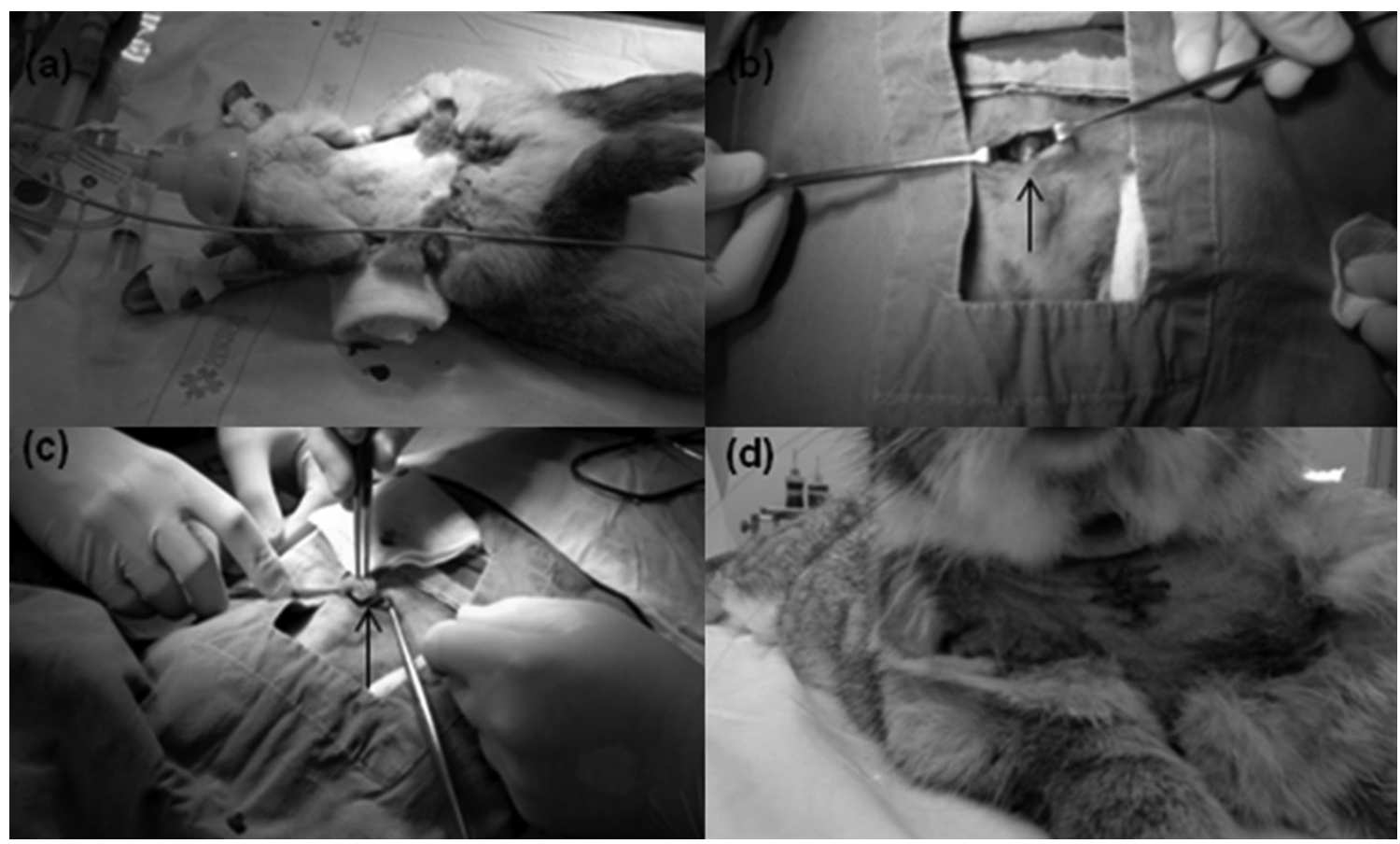

Figure 5. Tracheotomy procedure (a) rabbit in dorsal decubitus position; (b) exposition of trachea (arrow); (c) stent positioning through aperture (arrow); (d) posteoperatory sewing location.

During postoperative period, the animal showed stridor, but kept respiratory saturation. After three weeks, towards bronchoscopy, it was possible see the stent in the same initial position, without granuloma formation, and slight fibrosis appearance at implant's proximal end. There was no infectious process, breathe obstruction by fistula or emphysema occurrence. The present results are partial, lacking a long term observance for further conclusions.

\section{Conclusions}

The functional groups presented in the FTIR of the different blend compositions match the molecular structures of the polymers used. The variation of $\mathrm{CH}_{2}$ and $\mathrm{CH}_{3}$ stretchings and bends is directly linked to the quantity of IR in the blend. The bands relative to the $\mathrm{C}=\mathrm{C}$ vibrations are weak, characteristic of IR cis arrangement. Such intensity shows that no cross-linked bonds appeared between the polymeric chains. The compounds did not present structural changes due to the use of organic solvent. The miscibility between the raw polymers is partial in compositions like $60 / 40$, fact that may be seen in the DSC curves, analyzing the approximation between glass transition temperatures. The tensile test shows that the Poly(Isoprene) added to Poly (Lactic-coGlycolic Acid) did not affected significantly the rupture strain results. However, there is a relevant reduction in material's Young modulus, tensile stress and tenacity. The addition of IR also stimulates a change from fragile behavior, presented by raw PLGA, to ductile behavior. The composition did not affected the blend hardness, since the values stayed between the raw polymers hardness. An analysis of cell viability concludes that the blend is appropriate for application in the corporeal environment. Given that the Cell Lysis did not observe a significant difference between groups, the blend can be considered biocompatible. Despite the need for further time of observation, the polymeric stent showed to be reasonable to studies at in vivo environment.

\section{Acknowledgements}

The authors would like to thank the Coordenadoria de Aperfeicoamento de Pessoal de Nivel Superior (CAPES) and the Conselho Nacional de Desenvolvimento Científico e Tecnológico (CNPq) for the financial support of this study.

\section{References}

1. Kadla, J. \& Kubo S. - Compos, 35, p.395 (2003).

2. Pandey, A.; Pandey, G. \& Aswath, P. - J. Mech. Behav. Biomed. Mat., 1, p.227 (2008). PMid:19627787. http:// dx.doi.org/10.1016/j.jmbbm.2007.12.001 
3. Rezende, C. A. \& Duek, E. A. R. - Polímeros, 13, p.36 (2003). http://dx.doi.org/10.1590/S0104-14282003000100009

4. Isotalo, T. M.; Nuutine, J. P.; Vaajanen, A.; Martikainen, P.; Laurila, M.; Törmälä, P.; Talja, M. \& Tammela, T. L. - BJU Intern., 97, p.856 (2005).

5. Balabanian, C. A.; Coutinho-Netto, J.; Lamano-Carvalho, T. L.; Lacerda, S. A. \& Brentegani, L. G. - J. Oral Sci., 48, p.201 (2006). http://dx.doi.org/10.2334/josnusd.48.201

6. Mano, E. B. - "Química Experimental de Polímeros", Edgard Blücher, São Paulo (2004).

7. Stevens, M. P. - "Polymer Chemistry: An Introduction", Oxford University Press, New York (1999).

8. Chen, C. C.; Chueh, J. Y.; Tseng, H.; Huang, H. M. \& Lee, S. Y. - Biomat., 24, p.1167 (2003). http://dx.doi. org/10.1016/S0142-9612(02)00466-0

9. Lipatov, Y. - Prog. Pol. Sci., 27, p.1721 (2002). http:// dx.doi.org/10.1016/S0079-6700(02)00021-7

10. Jin, H. J.; Chin, I. J.; Kim, M. N.; Kim, S. H. \& Yoon, J. S. - Eur. Pol. J., 36, p.165 (2000). http://dx.doi.org/10.1016/ S0014-3057(99)00041-5

11. Talja, M.; Tammela, T.; Petas, A.; Valimaa, T.; Taari, K.; Biherkoski, E. \& Tormala, P. - J. Urol., 154, p.2089 (1995). http://dx.doi.org/10.1016/S0022-5347(01)66702-8

12. Tsutsui, H.; Kubota, M.; Yamada, M.; Suzuki, A.; Usuda, J.; Shibuya, H.; Miyajima, K.; Sugino, K.; Ito, K.; Furukawa, K. \& Kato, H. - As. Pacif. Soc. Respir., 13, p.632 (2008).

13. Wood, D. E.; Liu, Y. H.; Vallières, E.; Jones, R. K. \& Mulligan, M. S. - Ann. Thor. Surg., 76, p.167-174 (2003). http://dx.doi.org/10.1016/S0003-4975(03)00033-X

14. Dumon, J. F. - Chest, 97, p.328 (1990). PMid:1688757. http://dx.doi.org/10.1378/chest.97.2.328

15. Thistlethwaite, P. A.; Yung, G.; Kemp, A.; Osbourne, S.; Jamieson, S. W.; Channick, C. \& Harrell, J. - J. Thor. Card. Surg., 136, p.1569 (2008). PMid:19114208. http://dx.doi. org/10.1016/j.jtcvs.2008.08.021

16. Xavier, R. G.; Sanches, P. R. S.; Macedo Neto, A. V.; Kuhl, G.; Vearick, S. B. \& Michelon, M. D. O. - J. Bras. Pneum., 34, p.21 (2007). http://dx.doi.org/10.1590/S180637132008000100005

17. Brouwer, A. M.; Raja, T. N.; Biemans, K.; Nabuurs, T. \& Tennebroek, R. - Ann. N.Y. Acad. Sci., 1130, p.157(2008). PMid:18596344. http://dx.doi.org/10.1196/ annals. 1430.014

18. Mano, E. B. - "Polímeros como Materiais de Engenharia", Edgard Blücher, São Paulo (2004).

19. Antoniou, E. \& Alexandridis, P. - Eur. Pol. J., 46, p.324 (2010). http://dx.doi.org/10.1016/j.eurpolymj.2009.10.005

20. Callister Junior, W. D. - "Materials Science and Engineering: an Introduction”, John Wiley \& Sons Inc, Salt Lake City (1997).

21. Hanson, S.; Lalor, P. A.; Niemi, S. M.; Northup, S. J.; Ratner, B. D.; Spector, M.; Vale, B.H. \& Willson, J. E. - "Testing Biomaterials", in: Biomaterials Science, D. B. Ratner ed., Academic Press, San Diego (1996). http:// dx.doi.org/10.1016/B978-0-08-050014-0.50010-9

22. Dos Santos, R. L.; Pithon, M. M.; Martins, F. O.; Romanos, M. T. V. \& Ruellas, A. C. O. - Orth. Cran. Res., 13, p.28
(2010). PMid:20078792. http://dx.doi.org/10.1111/j.16016343.2009.01469.x

23. Mee, C. J.; Harris, H. J.; Farquhar, M. J.; Wilson, G.; Reynolds, G.; Davis, C.; Ijzendoorn, S. C. D.; Balfe, P. \& McKeating, J. S. - J. Virol., 83, p.6211 (2009).

24. Koschutnig, K.; Heikkinen, S.; Kemmo, S.; Lampi, A. M.; Piironen, V. \& Wagner, K. H. - Toxic. InVit., 23, p.755 (2009). PMid:19328846. http://dx.doi.org/10.1016/j. tiv.2009.03.007

25. Tsuneizumi, Y.; Kuwahara, M.; Okamoto, K. \& Matsumura, S. - Pol. Degrad. Stab., 95, p.1387 (2010). http://dx.doi. org/10.1016/j.polymdegradstab.2010.01.019

26. Motta, A. C. \& Duek, E. A. R. - Rev. Mat., 11, p.340 (2006).

27. Motta, A. C. \& Duek, E. A. R.- Polímeros, 16, p.26 (2006). http://dx.doi.org/10.1590/S0104-14282006000100008

28. Cibulková, Z.; Polovková, J.; Lukes, V. \& Klein, E. - J. Therm. Anal. Calorim., 84, p.709 (2006). http://dx.doi. org/10.1007/s10973-005-7547-1

29. Klöpffer, W. - "Introduction to Polymer Spectroscopy", Springer-Verlag, Frankfurt (1984). http://dx.doi. org/10.1007/978-3-642-69373-1

30. Queiroz, D. P. - "Diagrama de fases, propriedades térmicas e morfológicas de blendas de Poli (ácido láctico) e Poli (metacrilato de metila)", Tese de Doutorado, Universidade Estadual de Campinas, Brasil (2000).

31. Silverstein, R. M. - "Identificação Espectrométrica de Compostos Orgânicos”, LTC, Rio de Janeiro (2005).

32. Jahno, V. D - "Síntese e Caracterização de Poli (L-Ácido Láctico) para Uso como Biomaterial”, Dissertação de Mestrado, Universidade Federal do Rio Grande do Sul, Brasil (2005).

33. Ciesielski, A. - "An Introduction to Rubber Technology", Rapra Technology Limited, Shawbury (1999).

34. Upadhyay, D.; Mohanty, S.; Nayak, S. K.; Parvaiz, M. R. \& Panda, B. P. - App. Pol. Sci., 120, p.932 (2011). http:// dx.doi.org/10.1002/app.33106

35. Siddaramaiah, M. N.; Kumar, M. N. S. \& Nando, G. B. - J. App. Pol. Sci., 121, p.3070 (2010). http://dx.doi. org/10.1002/app.33957

36. American Society for Testing and Materials - ASTM. - "D2240: Standard Test Method for Rubber Material - Durometer Hardness", West. Conshohocken, 8 p. (2000).

37. Associação Brasileira de Normas Técnicas - ABNT. - "NBR ISO 10993-01", Rio de Janeiro (2003).

38. Franz, A.; König, F.; Skolka, A.; Sperr, W.; Bauer, P.; Lucas, T.; Watts, D. C. \& Schedle, A. - Dent. Mater., 23, p.1438 (2007). PMid:17688932. http://dx.doi.org/10.1016/j. dental.2007.05.014

39. Hsu, C. L.; Shyu, M. H.; Lin, J. A.; Yen, G. C. \& Fang, S. C. - Food Chem., 127, p.1 (2011).

Received: 07/16/12

Revised: 02/15/13

Accepted: 06/05/13 